Lolowah Abdulkarim Abrahym Hanan Salah EL-Deen Mohamed Amal Mohamed Hassan Otaiba

\title{
Reinforcing moderation: University instructors' role in incorporating social networks to promote critical thinking among female Umm Al-Qura students
}

Lolowah Abdulkarim Abrahym ALQowaify

(Sunna Prophet Mohammed Department)

Hanan Salah EL-Deen Mohamed EL-Halawany

(Islamic and Comparative Education Department)

Amal Mohamed Hassan Otaiba

(Islamic and Comparative Education Department)

ملخص البحث باللغة العربية

هدف البحث الحالي إلى الكثف عن الدور الذي يمكن أن يؤديه أعضاء هيئة

التدريس في جامعة أم القرى؛ من أجل تعزيز الوسطية لاى الطالبات؛ وذلك عن طريق

تتمية مهارات التفكير الناقد لديهن؛ من خلال توظيف شبكات التواصل الاجتماعي في لني الأنشطة الصفية.

ولقد كشفت النتائج التي أسفرت عنها الدراسة الأولى من المشروع البحثي، من إعداد

الباحثات الحاليات؛ عن أن الوسطية نسق ثقافي له آلياته العقلية، تتصمن سلسلة من الن

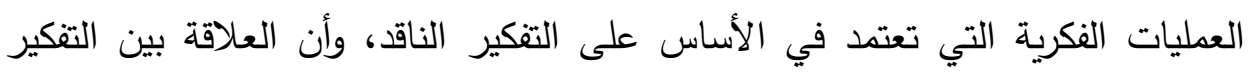
الناقد وبين الوسطية علاقة مهمة وتبادلية ومركزية. وعليه فقد تأكد أن تعزيز الوسطية الوبنية

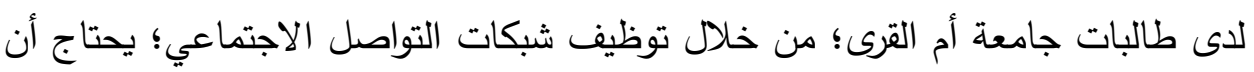
تمتلك الطالبات مهارات التفكير الناقد بداية.

وحيث يقع الدور الأساس في تعليم الطالبات مهارات التقكير الناقد على الأستاذ الجامعي؛ لذا فقد قامت الباحثات في الدراسة الحالية ( وهي الدراسة الثانية من المشروع مجلة كلية التربية- جامعة عين شمس 43 () العدد الثاني والأربعون (الجزء الاول) 2018 
Reinforcing moderation: University instructors' role in incorporating social networks to promote critical thinking among female Umm Al-Qura students

البحثي)، بتصميم تجربة؛ في محاولة للكثف عن أثرها في زيادة امتلاك الطالبات (عينة

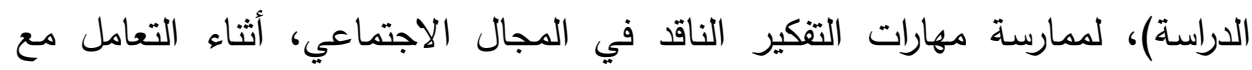
شبكات التواصل الاجتماعي، وقد تم استخداد شبكة (الواتس أب)، من خلال الأنشطة الصفية التي يقدمها عضو هيئة التدريس في مقرر (المدخل إلى التربية)، والذي يتم تدريسه لطالبات الإعداد التربوي بكلية التربية جامعة أم القرى (الفصل الدراسي الثاني2017/2016). وقد اعتمدت الباحثات في تصميم التجربة على التصنيف الذي قدمه باير (Beyer, 1985) لمهارات التفكير الناقد، والذي يعتمد على العمليات العقلية العليا. وكان من أبرز النتائج التي أسفر عنها البحث: إن إدماج تكنولوجيا المعلومات

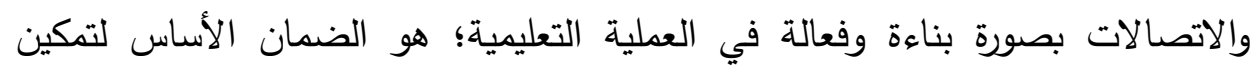

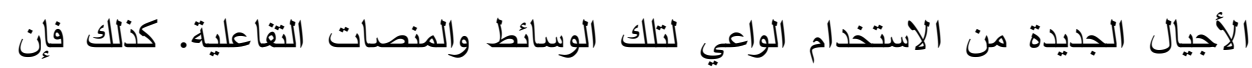
إدماج مهارات التفكير الناقد في التعليم الجامعي، وتدريب الطلاب على ممارسته في جميع شؤون حياتهم؛ هو ضرورة حتمية لتطوير وتحسين منظومة التعليم العالي في الجامعات السعودية، والمدخل إلى بناء المجتمع الحيوي الذي تسعى خطة المملكة العربية السعودية 2030 إلى تحقيقه.

الكلمات المفتاحية: التفكير الناقد - الوسطية - شبكات التواصل الاجتماعي - جامعة أم القرى.

مجلة كلية التربية- جامعة عين شمس 44 () العدد الثانى والأربعون (الجزء الاول) 2018 


\title{
Reinforcing moderation: University instructors' role in incorporating social networks to promote critical thinking among female Umm Al-Qura students
}

\author{
Lolowah Abdulkarim Abrahym ALQowaify \\ (Sunna Prophet Mohammed Department)
}

Hanan Salah EL-Deen Mohamed EL-Halawany

(Islamic and Comparative Education Department)

\author{
Amal Mohamed Hassan Otaiba \\ (Islamic and Comparative Education Department)
}

\begin{abstract}
Results emerged from this research support the assumption that critical thinking is an integral element in transforming traditional forms of Saudi education into a constructive one. In the interim, new social media is important for supporting constructive learning and critical thinking practice, because new social media are an integral element of the learning environment of younger Saudi generations. The results also indicate that the traditional teacher centered learning context can never develop critical thinking skills in students, and opening the learning platform for Saudi students to take the lead position is the only guarantee that students will be able to master and practice critical thinking skills in a manner that transcends the learned experiences, bringing these skills to real life situations and to the workplace, particularly since the release of the monarchy's decrees allowing Saudi females the right to drive cars and to travel without the permission of their custodians.

In the meantime, the country's vision 2030 targets to establish a variant society whose members adhere to the moderate
\end{abstract}

$$
\text { مجلة كلية التربية- جامعة عين شمس } 45 \text { () العدد الثانى والأربعون (الجزء الاول) } 2018
$$


Reinforcing moderation: University instructors' role in incorporating social networks to promote critical thinking among female Umm Al-Qura students

Islamic teachings while vividly interacting with the global society. They are expected to live a harmonious life where their national awareness sync with their international belonging. Research results reveal that training new Saudi generation to master critical thinking paves their paths to lead such life.

They are also expected to develop a deep appreciation of their cultural heritage while enjoying a good life in a modern information society. Therefore, a constructive education that invests information technology, guarantees the improvement of their ability to use information technology consciously.

These new sociocultural transitions need an educational revolution based on moderation and tolerance that will protect women's emergence into the expected variant society and its labor market from the backlashes of extremism. Specially, with the growing need for new professional sectors as explained in the 2030 vision education reforms must be at the heart of any Saudi debate and plan.

Keywords: critical thinking - moderation - social networks Umm AL-Qura university 
Lolowah Abdulkarim Abrahym Hanan Salah EL-Deen Mohamed Amal Mohamed Hassan Otaiba

\section{Reinforcing moderation: University instructors' role in incorporating social networks to promote critical thinking among female Umm Al-Qura students}

\section{Lolowah Abdulkarim Abrahym ALQowaify}

(Sunna Prophet Mohammed Department)

Hanan Salah EL-Deen Mohamed EL-Halawany

(Islamic and Comparative Education Department)

Amal Mohamed Hassan Otaiba

(Islamic and Comparative Education Department)

"Mastery of thinking skills or strategies is not...or ought not to be ...the ultimate goal of our efforts. We seek not simply to produce individuals who have technical expertise in thinking but to produce individuals who can think to produce better products of skilled thinking and who are willing to do so". (Beyer, 1988, p. 7).

\section{Introduction}

Networks are powerful tools for connecting people worldwide. They are intended to make life on earth happier and more peaceful. Unfortunately, these tools have been manipulated to spread fanaticism and extremism instead of fostering tolerance and peaceful coexistence. "A simple search on Facebook, Twitter, You Tube, etc. can lead one to find endless amounts of terrorist propaganda" (Larzelere, 2015, p. 37).

InJeong Yoon (2016) in his research "Why is it not just a joke? Analysis of internet memes associated with racism and hidden

$$
\text { مجلة كلية التربية- جامعة عين شمس } 47 \text { () العدد الثانف والأربعون (الجزء الاول) } 2018
$$


Reinforcing moderation: University instructors' role in incorporating social networks to promote critical thinking among female Umm Al-Qura students

ideology of colorblindness", presents shocking facts. In his analysis of internet memes, he discovered that most internet memes about racism perpetuate color-blindness by mocking people of colour. Therefore, he recommended that, internet materials should be critically analysed and challenged to unveil the covert ideologies they embrace (94).

This issue takes on more serious dimension when considering that students now live in a world where obtaining information is no longer a concern, while interpreting information and understanding its implicit meanings has become the actual problem. Therefore, the proper use of social media tools should be at the heart of any educational effort. This new educational context demands an increased awareness on the part of educators about the critical thinking skills students need to become fully responsible citizens (Gavilan, Martinez-Navarro, \& Fernández-Lores, 2017).

According to Paul and Elder (2003) students who master critical thinking will show evidences of acquiring seven traits "intellectual humility, intellectual courage, intellectual empathy, intellectual integrity, intellectual perseverance, confidence in reason, and intellectual autonomy" (28).

Therefore, teaching critical thinking to students of the information generation is considered crucial. However, different studies argued that critical thinking is not fostered in Saudi education negatively affecting students' cognitive and moral progress (Al-Saggaf, 2011; Aljaad, 2016; ALQowaifly, ELHalawany, \& Otaiba, 2017; AShaya \& Batihah, 2013).

Hariri (2010) argued that in most Islamic communities, including Saudi Arabia, university students are captured by the temptations of social network tools, but this has seduced many of them to embrace extremism and prejudice. In fact, social networks have turned into a poisoned dagger that has assassinated moderation among the young generation, who pointed their weapon at the chest of their communities, families, and countries.

$$
\text { مجلة كلية التربية- جامعة عين شمس } 48 \text { () العدد الثان والأربعون (الجزء الاول) } 2018
$$


Lolowah Abdulkarim Abrahym Hanan Salah EL-Deen Mohamed Amal Mohamed Hassan Otaiba

In this realm, ALQowaifly et al. (2017) in their research, "The Factual Conducts of Umm A1-Qura Female Students on Social Networks in a Way that Reflects Moderation", concluded that university instructors are responsible for including social networking tools in their teaching to promote moderation according to the true spirit of Islam because moderation is not just a theoretical concept but a cultural pattern with a series of intellectual processes that rely primarily on critical thinking. ALQowaifly et al. argued that this task can only be fulfilled if the teaching of critical thinking skills becomes the goal of university teaching.

This conclusion represents the fertile soil nurtured by the current research, which is the second phase of a larger research project entitled "Investing Social Networks in Reinforcing Moderation among Saudi University Students (The Present and the Future)". In this phase, the researchers designed an experiment to investigate the role of university instructors in incorporating social networks into their teaching to promote critical thinking skills among female Umm Al-Qura students to reinforce moderation. The assumption raised in this research phase is that students' involvement in social networks during class activities will allow a deeper critical analyses of the posted comments than that allowed by traditional oral discussions (Thormann, Gable, Fidalgo, \& Blakeslee, 2013, p. 297).

In this scenario, instructors will function as moderators who are responsible for fulfilling 'starter-wrapper' duties. They should initiate discussions and support them. Instructors must steer discussions, as sometimes students are reluctant to engage in complex or unpopular topics and encourage group interaction by validating contributions and connecting posts allow students to learn from their peers (Thormann \& Fidalgo, 2014; Winograd, 2000).

Through this process, students will learn to appreciate innovative ideas, extend discussions with questions and observations, draw attention to opposing perspectives, encourage

مجلة كلية التربية- جامعة عين شمس 49 () العدد الثان والأربعون (الجزء الاول) 2018 
Reinforcing moderation: University instructors' role in incorporating social networks to promote critical thinking among female Umm Al-Qura students

debate, practice tolerance with disagreements, and unify threads to find a middle ground. These practices all present the pillars and core of moderation from an Islamic perspective. The Prophet Mohammad, peace be upon him, represents the complete living idol of moderation, from Muslims' perspectives. He calls his followers to embrace "Moderation, moderation". He, peace be upon him, consistently won the heart of his followers with his flexibility, understanding, and open mind. He always encouraged his fellow Muslims to go beyond tolerance to learn, listen, and recognize others' dignity and right to express their minds freely (Laurence, 2007, p. 132).

Based on this background, that the current research is developed to answer the following questions:

(1) Why is teaching critical thinking in University education became a necessity nowadays?

(2) What difference social networks can make in transforming traditional classrooms?

(3) What type of changes can the incorporation of social networks make in university instructors' roles?

(4) Are there significant differences between pre-test scores and post-test scores on the critical thinking test?

\section{Hypotheses}

The current research attempts to examine the following hypotheses:

(1) There are significant differences between the pre-test scores and post-test scores on the critical thinking test related to students' ability to distinguish truth from assumption.

(2) There are significant differences between the pre-test scores and the post-test scores on the critical thinking test related to students' ability to distinguish between relevant and irrelevant information

مجلة كلية التربية- جامعة عين شمس 50 () العدد الثانى والأربعون (الجزء الاول) 2018 
Lolowah Abdulkarim Abrahym Hanan Salah EL-Deen Mohamed Amal Mohamed Hassan Otaiba

(3) There are significant differences between the pre-test scores and the post-test scores on the critical thinking test related to students' ability to evaluate information validity.

(4) There are significant differences between the pre-test scores and the post-test scores on the critical thinking test related to students' ability to identify the deductive assumptions.

(5) There are significant differences between the pre-test scores and the post-test scores on the critical thinking test related to students' ability to identify logical misconceptions.

(6) The critical thinking training that students received positively affects their evaluation of the course scenario and activities.

\section{Significance of the Research}

1. The present document is the second research that complements a research project, providing the Arabic library with a type of information that shows the advantages of drawing on social networks for developing critical thinking among students. This would be achieved through class activities of university syllabuses; hence, fostering moderate thinking. Results of the previous research have underscored the fact that both critical and moderate thinking are closely interrelated.

2. This research explores an important segment of female students in the College of Education in Umm Al-Qura University. They are a host of promising teachers who will educate future generations how to think.

3. The research provides an empirical model of using social networks to develop critical thinking among university students. Such model can be adopted by professors with their students through class activities of the syllabuses they teach.

4. The practical significance of this research is represented in its results, which would contribute to using social networks in the development of critical thinking among university students, that fosters moderate thinking in a scientific and

مجلة كلية التربية- جامعة عين شمس 51 () العدد الثان والأربعون (الجزء الاول) 2018 
Reinforcing moderation: University instructors' role in incorporating social networks to promote critical thinking among female Umm Al-Qura students

balanced ways; hence, safeguarding them from deviant and misguided thoughts.

First: The Importance of Critical Thinking and its Learning Necessity

\section{1) The importance of critical thinking for learners}

Critical thinking is a pedagogical issue that has been in focus by psychologists and pedagogists in recent decades, as a key instrument to ensure effective knowledge development that allows individuals to use their maximum potentials to positively interact with their environment. Most empirical studies, where programs and experiences have been used for the development of such type of thinking skills (AlThubaiti, 2006, p. 67), revealed that these skills have proven useful to learners on several aspects. They enable a deeper understanding of the learners' knowledge / (epistemological) content, and lead them to independent thinking, setting them free from dependency and self-centeredness. They inspire them to ask, research, and validate the truth based on adequate investigation. They give meaning to school experiments and foster their endeavors to apply and practice them. they improve learners' educational achievement. They allow them to be more positive, interactive and engaged in the learning process. They boost learners' ability to find solutions for their problems and take appropriate decisions accordingly. They promote self-confidence and self-esteem, and allow learners the opportunity to grow, develop and innovate.

In short, the development of critical thinking skills has gained ultimate importance in our fast-evolving world, as they are enablers of effective participation in society, and provide learners with various experiences that prepare them to adapt with the present life requirements and to succeed in the future. As education intends to equip citizens with the necessary ability to take decisions and make their own choices, based on the right to free choice, educators are

$$
\text { مجلة كلية التربية- جامعة عين شمس } 52 \text { () العدد الثانف والأربعون (الجزء الاول) } 2018
$$


Lolowah Abdulkarim Abrahym Hanan Salah EL-Deen Mohamed Amal Mohamed Hassan Otaiba

required to pay special attention to develop such type of thinking (Al Mughaseeb, 2006).

\section{2) Teaching critical thinking}

Teaching critical thinking involves the expansion of individual intellectual processes, by unleashing the power to explore beyond the existing instinctive stances and concepts and averting simple sensorial experiences. Critical thinking skills are acquired through a consistent education, starting with basic thinking skills, and gradually reaching higher thinking processes. If given the opportunities of training, application and actual practice, each student can think critically. A number of opinions or trends exist regarding the method of teaching or training on critical thinking; however, these opinions virtually revolve around two main methods:

- Teaching critical thinking as an independent subject, among other subjects, through programs and syllabuses in the form of extracurricular activities and exercises. Many specialized programs were developed to improve the skills of such type of thinking, and a specialized trainer usually provides students with this training. The above method has the advantage of making learners realize the importance of the subject they learn and develop a sense of the thinking processes they undertake; It also makes the assessment and evaluation of the critical thinking process more accurate.

- To incorporate critical thinking into various study subjects, which require qualified teachers and sufficient training time for thinking processes. This method has the advantage of continuously stimulating the educational process, prompting learners to use the thinking processes in various subjects, and providing a deeper application and understanding of the knowledge content of such subjects, as well as a better ability to comprehend them. Modern trends have emerged to combine both methods in teaching critical thinking, in order to leverage the advantages and positive aspects of them both (Radwan, 2000, p. 11).

$$
\text { مجلة كلية التربية- جامعة عين شمس } 53 \text { () العدد الثانف والأربعون (الجزء الاول) } 2018
$$


Reinforcing moderation: University instructors' role in incorporating social networks to promote critical thinking among female Umm Al-Qura students

\section{3) The teachers' role in critical thinking}

Teachers are an important success factor of critical thinking teaching programs, as the application of any critical thinking plan depends on the teaching quality provided in the classrooms, and is one of the most important characteristics that teachers should have in order to provide a classroom environment conducive to the success of teaching and learning critical thinking, as follows: Teachers should be keen to listen to learners, allow them sufficient time to reflect and think, grant them opportunities for discussion and self-expression, and encourage active learning based on generating ideas by posing questions related to higher thinking skills. They also should accept their opinions, appreciate their thoughts, respect their individual differences, attempt to boost their self-confidence, and provide them with appropriate feedback (Al Mughaseeb, 2006, p. $5)$.

Upon discussing the significant role of teachers towards activating critical thinking among students, we should recognize his/her role of leading by example, in order to facilitate critical thinking process among students. These roles include the following:

- Teachers are the planners of the teaching process: Teachers plan the performance targets in their daily lessons and classes, as well as samples of questions, study subjects and activities that define the educational targets and means to achieve them.

- Teachers are the designers of classroom environment: Classroom environment, built on group dynamics and democratic participation, promotes a concerted group environment, where expression of opinions, free exploration, cooperation, support, self-confidence and encouragement are appreciated.

مجلة كلية التربية- جامعة عين شمس 54 () العدد الثان والأربعون (الجزء الاول) 2018 
Lolowah Abdulkarim Abrahym Hanan Salah EL-Deen Mohamed Amal Mohamed Hassan Otaiba

- Teachers are initiators: This is achieved by venturing into a variety of subjects and activities, and introducing situations focusing on real life problems. Posing questions is the method used to engage student's effectively.

-Teachers are maintainers of communication: The easiest task that teachers can undertake, is to stimulate the interest of students with true and enjoyable issues; however, it is difficult to keep them attentive, which requires the use of stimulating subjects, activities and questions.

- Teachers are the source of knowledge: Teachers often play the role of knowledge providers, as they prepare information and provide the necessary equipment and materials to be used by students, while they avoid giving them answers that hamper their eager pursuit to reach conclusions by themselves.

- Teachers play a probing role: This is achieved by posing subtle and insightful questions that require them to justify and corroborate their ideas, assumptions and conclusions.

- Teachers are role models: Teachers are role models in terms of the conduct they adopt, showing interest, inquisitiveness, critical thinking and reading, active engagement, compassion, and the desire to explore their thoughts in pursuit of evidence.

\section{Second: Method}

\section{Research design}

Since this research seeks to explore the role of university instructors in developing Saudi female students' critical thinking skills through the inclusion of social networks in class activities, the research adopted the following approaches: (1) The descriptive analytical approach, where researchers reviewed and analysed related literature to explain and describe the phenomena under investigation, (2) A pre-experimental approach that employed one

$$
\text { مجلة كلية التربية- جامعة عين شمس } 55 \text { () العدد الثانف والأربعون (الجزء الاول) } 2018
$$


Reinforcing moderation: University instructors' role in incorporating social networks to promote critical thinking among female Umm Al-Qura students

group design. The group was tested by using a pre-and post-test. It was a critical thinking test designed by the researchers, (3) An evaluation survey, was implemented at the end of the term. The survey included 25 close- ended Likert scale questions based on a 5choice scale ranging from strongly agree, agree, neutral, disagree, to strongly disagree. This certified survey aimed to explore students' degree of satisfaction with the course scenario and activities.

\section{Variables}

The dependent variables were controlled in this research through applying a pre-and post-test on the same group. The group was taught by the same teacher throughout the whole experiment. The dependent variables are identified as the class activity assigned as part of the "Introduction to Education" course, and the specialization of the research participants as they were all general diploma Saudi female students major in English, the same pre-and post-test was applied. The independent variable is the instructor's integration of social networks as "WhatsApp" and "Instagram" in a class activity to improve student's ability to practice critical thinking.

\section{Participants}

Research participants were general diploma female Saudi students at Umm Al-Qura University major in English $(n=31)$. They registered to take the "Introduction to Education" course in the second term of the school year 2016/2017.

\section{Instrument}

The researchers used a critical thinking test they designed. The test was subjected to review by experts before using it to collect data. The test consisted of five parts, and each part consisted of an advertisement for a certain product all were exported from the internet. Each advertisement was meant to measure one critical thinking skill as classified by Beyer (1985): (1) The distinction between truth and assumption, (2) The distinction between relevant and irrelevant information, (3) The evaluation of information

$$
\text { مجلة كلية التربية- جامعة عين شمس } 56 \text { () العدد الثانف والأربعون (الجزء الاول) } 2018
$$


Lolowah Abdulkarim Abrahym Hanan Salah EL-Deen Mohamed Amal Mohamed Hassan Otaiba

validity, (4) The identifying the deductive assumptions, (5) The identifying logical misconceptions.

In addition, the "students' course evaluation survey" was used to measure students' degree of satisfaction with the course scenario and activities as well as the performance of the instructor.

\section{The ideological framework of the course activity}

Course work and activities are designed and developed within the constructive framework. Constructivism is a learner-centered pedagogical approach, "in which the problems and scenarios reflect students' lives" (Thormann et al., 2013, p. 297). Constructivism assumes that learning is a social process within which students construct their own meaning of the presented knowledge. Therefore, it requires alternative teaching techniques where classroom discussions and project-based assignments replace traditional classroom lecturing and tests (Koohang, Riley, Smith, \& Schreurs, 2009; Overbaya, Patterson, Vasua, \& Grablec, 2010).

Similarly, Löfström and Nevgi (2006) proposed that to transform traditional passive leaning environment into a constructivist one, information technology must be integrated in an innovative manner. Within this context knowledge is collectively constructed and connected to the real world. In addition, learners share learning benefits as they work to accomplish common goals. These actions end with the development of students' recognition of responsibility, commitment, and empowerment (Löfström \& Nevgi, 2006).

In other words, instead of traditional 'face to face' teaching, in which the instructor pours information into students' brains, while students passively memorize, the integration of social media into the classroom encourages students to engage critically with the new information through, analysis, problem-solving and interpretation (Ladyshewsky, 2006; Murphy \& RodriguezManzanares, 2009).

"It is assumed that the ability to learn through social interaction with others and with oneself is central to knowledge

مجلة كلية التربية- جامعة عين شمس 57 () العدد الثاني والأربعون (الجزء الاول) 2018 
Reinforcing moderation: University instructors' role in incorporating social networks to promote critical thinking among female Umm Al-Qura students

acquisition and formation. The benefit of integrating social media like WhatsApp and Instagram is that these virtual channels connect with students' daily life. Therefore, creating communities of practice and open platforms for discussions enlivens the traditional learning environment of the classroom. The open and free space social media offers empower students to take over their learning process by becoming active agents in knowledge creation" (Churcher, Downs, \& Tewksbury, 2014, p. 35).

This type of learning coincides with the Saudi National Transformation Program 2020 which asserts that one of its strategic objectives is "to improve the learning environment to stimulate creativity and innovation"(Kingdom of Saudi Arabia, 2016a, p. 60). The accomplishment of this objective will pave the road to the fulfilment some of the most strategic long-term goals the 2030 plan: "1- to establish positive values and build an independent personality for citizens. 2- provide citizens with knowledge and skills to meet the future needs of the labor market. 3- develop youth skills and leverage them effectively" (2016a, p. 60).

\section{The experiment}

A research project may either be cross-sectional or longitudinal. Cross- sectional research is used to describe a phenomenon at a particular time, whereas investigating a change and development over time is longitudinal research (Saunders, Lewis, \& Thornhill, 2014). This research is sectional, the experiment was carried out while teaching the Introduction to Education course, which occurred in the second term of the 2016/2017 school year.

The "Introduction to Education" course covers a wide range of topics, historical, cultural, and philosophical foundations of Saudi education. Throughout the course works and activities students are required to reflect and critique their educational experience, and construct their values and believes about teaching, learning, and schooling. They are also required to examine the role education can play in achieving Saudi National Transformation Program 2020.

$$
\text { مجلة كلية التربية- جامعة عين شمس } 58 \text { () العدد الثانف والأربعون (الجزء الاول) } 2018
$$




\section{Lolowah Abdulkarim Abrahym Hanan Salah EL-Deen Mohamed Amal Mohamed Hassan Otaiba}

The Saudi National Transformation Program 2020 is part of the "Saudi Arabia Vision 2030", that was adopted as a roadmap for a comprehensive economic and developmental transformation in the Kingdom of Saudi Arabia. To achieve the ambitious 2030 Vision, the "National Transformation Program 2020" was launched to build the institutional capacity and capabilities. The program was launched in 2016 and expected to achieve its targets by the end of 2020. Among its variant objectives, the program targets to pave the way for the private sector to participate more in the national economy. It targets to create 450.000 job opportunities in small and medium enterprises. For Saudi women in specific the program targets to empower women and materialize their economic potentials through increasing their participation in e-commerce (Kingdom of Saudi Arabia, 2016a, pp. 33,37).

Therefore, the experiment was designed to incorporate social networks in class activities to train young female Saudi students to think critically while planning and designing an e-commerce project. As Prince Mohammed Bin Salman bin Abdulaziz Al-Saud, the Crown Prince of Saudi Arabia and the Chairman of the Council of Economic and Development Affairs, explained in the introduction of the 2030 Vision that one of the main pillars of the 2030 vision is to reinforce the Kingdom's position as the leader of the Arab and Islamic world, and he acknowledged that "Our Kingdom is the Land of the Tow Holy Mosques, the most sacred sited on earth, and the direction of Kaabaa (Qibla) to which more than a billion Muslims turn at prayer" (Kingdom of Saudi Arabia, 2016 b, pp. 33,37). Upon that, the course activities were devoted to train students to think critically on how to establish an e-commerce project within the Islamic teachings.

The course activities were intended to train Saudi female students to consider social networks beyond socialization and entertainment purposes. The training was directed towards expanding their cognitive horizon by practicing critical thinking to signal their ability to practice moderation in real life situations.

مجلة كلية التربية- جامعة عين شمس 59 () العدد الثاني والأربعون (الجزء الاول) 2018 
Reinforcing moderation: University instructors' role in incorporating social networks to promote critical thinking among female Umm Al-Qura students

The plan was for the experiment to take six weeks, but due to the approach of the month of Ramadan, when all Muslims fast, King Salman issued a decree that all schools and universities must finish their works before Ramadan; this decreased the length of the experiment to four weeks rather than six. To compensate for this shortage in time, the researchers decided to increase the training hours per week to two hours rather than one.

Table 1 . The timetable of the experiment

\begin{tabular}{|c|c|c|c|}
\hline Session & Date & Time & Procedures \\
\hline 1 & $17 / 4 / 2017$ & 9-10am & $\begin{array}{l}\text { - Distributed the pre-test among } \\
\text { students and collect them after } \\
\text { completion. } \\
\text { - Divided students into groups of } \\
\text { 4. } \\
\text { - Create a shared account on } \\
\text { WhatsApp and Instagram. } \\
\text { - Explained the tasks students } \\
\text { need to fulfil. }\end{array}$ \\
\hline 2 & $17 / 4 / 2017$ & $1-2 \mathrm{pm}$ & $\begin{array}{l}\text { - } \text { To energize students' } \\
\text { participation in the class project } \\
\text { with enthusiasm, I presented a } \\
\text { video of an episode from a } \\
\text { programme entitled "I was } \\
\text { Enlighted by the Quran" } \\
\text { https://www.youtube.com/watch } \\
\text { ?v=JWRny15JrAc\&t=11s } \\
\text { - Discussed students' comments } \\
\text { on the video and how they can } \\
\text { extract ideas about launching an } \\
\text { Islamic e-commerce project. } \\
\text { Each group posted their final } \\
\text { comments on the common } \\
\text { account on WhatsApp. }\end{array}$ \\
\hline 3 & $24 / 4 / 207$ & $2-1 \mathrm{pm}$ & $\begin{array}{l}\text { - Each group selected a verse from } \\
\text { the Quran, to function as a logo } \\
\text { for their project and justified }\end{array}$ \\
\hline
\end{tabular}

مجلة كلية التببة- جامعة عين شمس 60 () العدد الثان والأربعون (الجزء الاول) 2018 


\section{Lolowah Abdulkarim Abrahym Hanan Salah EL-Deen Mohamed Amal Mohamed Hassan Otaiba}

\begin{tabular}{|c|c|c|c|}
\hline Session & Date & Time & Procedures \\
\hline & & & $\begin{array}{l}\text { their choice. } \\
\text { Each group posted their logo on } \\
\text { the WhatsApp account. } \\
\text { Each group created a set of } \\
\text { standards that Saudi women } \\
\text { must respect while establishing } \\
\text { an e-commerce project. } \\
\text { The session ended with all } \\
\text { groups discussing what they } \\
\text { have learned from this activity. }\end{array}$ \\
\hline 4 & $28 / 4 / 2017$ & $12-1 \mathrm{pm}$ & $\begin{array}{l}\text { - The session opened with all } \\
\text { groups discussing the project } \\
\text { standards they posted, and each } \\
\text { group had the chance to alter } \\
\text { their standards based on peers } \\
\text { comments and remarks. } \\
\text { - Each group picked an e- } \\
\text { commerce project for a Saudi } \\
\text { woman available on Instagram. } \\
\text { - Each group started to analyse the } \\
\text { e-project based on the standards } \\
\text { they created. } \\
\text { Each group shared their } \\
\text { conclusions with groups by } \\
\text { posting them on the class } \\
\text { WhatsApp account. }\end{array}$ \\
\hline 5 & $28 / 4 / 2017$ & $1-2 \mathrm{pm}$ & $\begin{array}{l}\text { - Each group started to design an } \\
\text { E-advertisement for the project } \\
\text { they selected. Then, they posted } \\
\text { it on the class WhatsApp } \\
\text { account. } \\
\text { At the end of the session, each } \\
\text { group summarized what they } \\
\text { had learned from this experience } \\
\text { and shared their comments and } \\
\text { remarks with the whole class by } \\
\text { posting them on the class } \\
\text { WhatsApp account. }\end{array}$ \\
\hline
\end{tabular}

$$
\text { مجلة كلية التربية- جامعة عين شمس } 61 \text { () العدد الثان والأربعون (الجزء الاول) } 2018
$$


Reinforcing moderation: University instructors' role in incorporating social networks to promote critical thinking among female Umm Al-Qura students

\begin{tabular}{|l|l|l|l|}
\hline \hline Session & Date & Time & Procedures \\
\hline 6 & $1 / 5 / 2017$ & $1-12$ pm & $\begin{array}{l}\text { All groups were involved in a } \\
\text { final open discussion regarding } \\
\text { all the e-advertisements they } \\
\text { created. }\end{array}$ \\
& $\begin{array}{l}\text { Students completed the post-test. } \\
\text { Students also completed "course } \\
\text { evaluation survey". } \\
\text { At the end of the session, each } \\
\text { student wrapped up the } \\
\text { experiences she gained from this } \\
\text { experiment. }\end{array}$ \\
\hline
\end{tabular}

\section{Results}

Calculated percentages and a paired-samples t-test were used to measure the differences between the means of scores of the students' scores in both the pre- and the post-test in relation to their ability to practice critical thinking. The difference is considered statistically significant when $(\mathrm{p}<0.05)$. The results are presented in the following tables in which the proposed hypotheses are tested.

(1) There is a significant difference between the pre-test scores and post-test scores on the critical thinking test related to students' ability to distinguish truth from assumption. 


\section{Lolowah Abdulkarim Abrahym Hanan Salah EL-Deen Mohamed Amal Mohamed Hassan Otaiba}

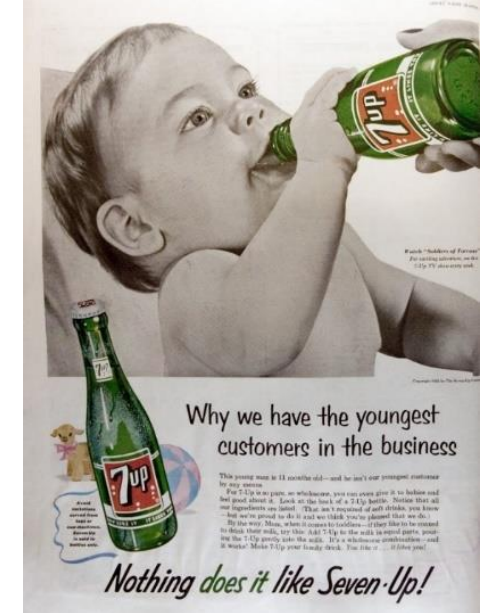

Table 2. The distribution of students' scores regarding to their ability to distinguish truth from assumption

\begin{tabular}{|c|c|c|c|c|c|c|c|}
\hline \multicolumn{5}{|l|}{ Pre-test } & \multicolumn{3}{|l|}{ Post-test } \\
\hline & & $\mathrm{N}$ & $\%$ & & & $\mathrm{~N}$ & $\%$ \\
\hline \multirow{3}{*}{ Truth } & Agree & 4 & 10 & \multirow{3}{*}{ Truth } & Agree & 4 & 13 \\
\hline & Not-Sure & 5 & 16 & & Not-Sure & 0 & 0 \\
\hline & Disagree & 22 & 71 & & Disagree & 27 & 87 \\
\hline \multicolumn{2}{|l|}{ Total } & 31 & 100 & \multicolumn{2}{|l|}{ Total } & 31 & 100 \\
\hline \multirow{3}{*}{ Assumption } & Agree & 19 & 61 & \multirow{3}{*}{ Assumption } & Agree & 21 & 68 \\
\hline & Not-Sure & 7 & 23 & & Not-Sure & 7 & 23 \\
\hline & Disagree & 5 & 16 & & Disagree & 3 & 10 \\
\hline \multicolumn{2}{|l|}{ Total } & 31 & 100 & \multicolumn{2}{|l|}{ Total } & 31 & 100 \\
\hline \multirow{3}{*}{ Exploitation } & Agree & 19 & 61 & \multirow{3}{*}{ Exploitation } & Agree & 26 & 84 \\
\hline & Not-Sure & 7 & 23 & & Not-Sure & 3 & 10 \\
\hline & Disagree & 5 & 16 & & Disagree & 2 & 6 \\
\hline \multicolumn{2}{|l|}{ Total } & 31 & 100 & \multicolumn{2}{|l|}{ Total } & 31 & 100 \\
\hline
\end{tabular}

This ad reveals no truth, just assumptions and exploitation. Table 2 shows that more students by the end of the course showed evidences that they are able to practice critical thinking compared to the beginning of the course. 
Reinforcing moderation: University instructors' role in incorporating social networks to promote critical thinking among female Umm Al-Qura students

Table 3. Independent Samples Test

\begin{tabular}{|c|c|c|c|c|c|c|}
\hline & Mean & $\mathrm{F}$ & Sig. & $\mathrm{t}$ & df \\
\hline \multirow{2}{*}{ Truth } & Pre-test & 1.24 & \multirow{2}{*}{1.613} & \multirow{2}{*}{.209} & .906 & \multirow{2}{*}{$\begin{array}{l}60 \\
59.821\end{array}$} \\
\hline & Post-test & 1.26 & & & .906 & \\
\hline \multirow{2}{*}{ Assumption } & Pre-test & 2.45 & \multirow{2}{*}{1.397} & \multirow{2}{*}{.242} & -704 & \multirow{2}{*}{$\begin{array}{l}60 \\
58.969\end{array}$} \\
\hline & Post-test & 2.58 & & & -704 & \\
\hline \multirow[b]{2}{*}{ Exploitation } & Pre-test & & \multirow[b]{2}{*}{9.268} & \multirow[b]{2}{*}{$.003 * *$} & & \multirow[b]{2}{*}{$\begin{array}{l}60 \\
54.901\end{array}$} \\
\hline & Post-test & $\begin{array}{l}2.45 \\
2.77\end{array}$ & & & $\begin{array}{l}1.890 \\
- \\
1.890\end{array}$ & \\
\hline
\end{tabular}

Table 3 shows that the first hypothesis is not confirmed, as the differences between students' scores at pre-test and post-test are not statistically significant. This result means that students are capable of recognizing that this ad contains assumptions and exploitation rather than truth.

(2) There is a significant difference between the pre-test scores and the post-test scores on the critical thinking test related to students' ability to distinguish between relevant and irrelevant information.

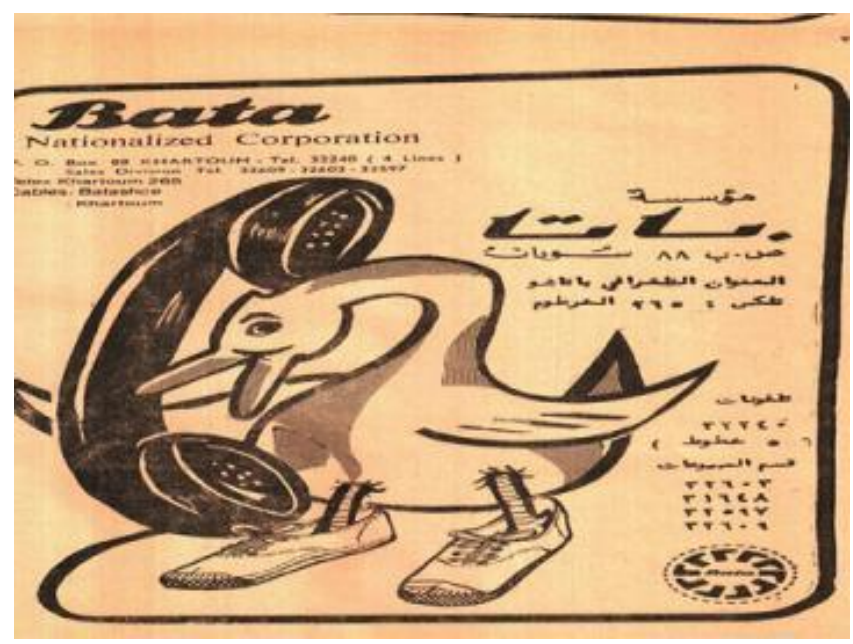

مجلة كلية التربية- جامعة عين شمس 64 () العدد الثانى والأربعون (الجزء الاول) 2018 
Lolowah Abdulkarim Abrahym Hanan Salah EL-Deen Mohamed Amal Mohamed Hassan Otaiba

Table 4. The distribution of students' scores in regarding to their ability to distinguish between relevant and irrelevant information.

\begin{tabular}{|c|c|c|c|c|c|c|c|}
\hline \multicolumn{5}{|l|}{ Pre-test } & \multicolumn{3}{|l|}{ Post-test } \\
\hline & & $\mathrm{N}$ & $\%$ & & & $\mathrm{~N}$ & $\%$ \\
\hline \multirow{3}{*}{$\begin{array}{l}\text { Clarity of } \\
\text { ideas }\end{array}$} & Agree & 1 & 3 & \multirow{3}{*}{$\begin{array}{l}\text { Clarity of } \\
\text { ideas }\end{array}$} & Agree & 1 & 3 \\
\hline & Not-Sure & 6 & 19 & & Not-Sure & 0 & 0 \\
\hline & Disagree & 24 & 77 & & Disagree & 30 & 97 \\
\hline \multicolumn{2}{|l|}{ Total } & 31 & 100 & \multicolumn{2}{|l|}{ Total } & 31 & 100 \\
\hline \multirow{3}{*}{$\begin{array}{l}\text { Proper } \\
\text { design }\end{array}$} & Agree & 1 & 3 & \multirow{3}{*}{$\begin{array}{l}\text { Proper } \\
\text { design }\end{array}$} & Agree & 1 & 3 \\
\hline & Not-Sure & 13 & 42 & & Not-Sure & 0 & 0 \\
\hline & Disagree & 17 & 55 & & Disagree & 30 & 97 \\
\hline \multicolumn{2}{|l|}{ Total } & 31 & 100 & \multicolumn{2}{|l|}{ Total } & 31 & 100 \\
\hline \multirow[b]{3}{*}{$\begin{array}{l}\text { Purpose } \\
\text { of the Ad }\end{array}$} & Agree & 2 & 6 & \multirow{3}{*}{$\begin{array}{l}\text { An } \\
\text { explicit } \\
\text { message } \\
\text { of the } \\
\text { importanc } \\
\text { e of the } \\
\text { product }\end{array}$} & Agree & 0 & 0 \\
\hline & Not-Sure & 13 & 42 & & Not-Sure & 2 & 6 \\
\hline & Disagree & 16 & 52 & & Disagree & 29 & 94 \\
\hline \multicolumn{2}{|l|}{ Total } & 31 & 100 & \multicolumn{2}{|l|}{ Total } & 31 & 100 \\
\hline
\end{tabular}

Table 4 shows that more students by the end of the course are able to recognize the problems in this ad that hindered the expression of ideas, design, and purpose than at the beginning of the course.

Table 5. Independent Samples Test

\begin{tabular}{|c|c|c|c|c|c|c|}
\hline & & Mean & $\mathrm{F}$ & Sig. & $\mathrm{t}$ & $\mathrm{df}$ \\
\hline \multirow{2}{*}{$\begin{array}{l}\text { Clarity of } \\
\text { ideas }\end{array}$} & Pre-test & 1.26 & \multirow{2}{*}{11.012} & \multirow{2}{*}{$.002 * *$} & 1.718 & 60 \\
\hline & Post-test & 1.06 & & & 1.718 & 53.642 \\
\hline \multirow{2}{*}{$\begin{array}{l}\text { Proper } \\
\text { design }\end{array}$} & Pre-test & 1.48 & \multirow{2}{*}{109.752} & \multirow{2}{*}{$.000 * *$} & 4.208 & 60 \\
\hline & Post-test & 1.03 & & & 4.208 & 35.902 \\
\hline \multirow{2}{*}{$\begin{array}{l}\text { Purpose } \\
\text { of the Ad }\end{array}$} & Pre-test & 1.55 & \multirow{2}{*}{58.322} & \multirow{2}{*}{$.000 * *$} & 4.009 & 60 \\
\hline & Post-test & 1.06 & & & 4.009 & 39.373 \\
\hline
\end{tabular}

Table 5 proves the second hypothesis, students at the end of the course and due the critical thinking training they received, are more

$$
\text { مجلة كلية التربية- جامعة عين شمس } 65 \text { () العدد الثان والأربعون (الجزء الاول) } 2018
$$


Reinforcing moderation: University instructors' role in incorporating social networks to promote critical thinking among female Umm Al-Qura students

capable of distinguishing between information related to the subject and irrelevant information than at the beginning of the course.

(3) There is a significant difference between the pre-test scores and the post-test scores on the critical thinking test related to students' ability to evaluate information validity.

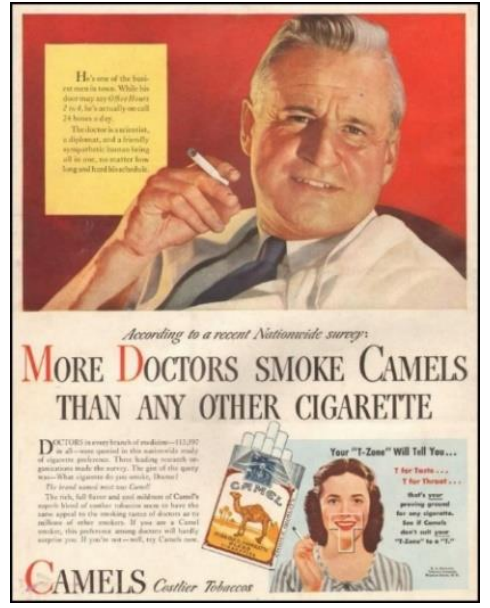

Table 6. The distribution of students' scores regarding their ability to evaluate information validity

\begin{tabular}{|c|c|c|c|c|c|c|c|}
\hline \multicolumn{5}{|l|}{ Pre-test } & \multicolumn{3}{|l|}{ Post-test } \\
\hline & & $\mathrm{N}$ & $\%$ & & & $\mathrm{~N}$ & $\%$ \\
\hline \multirow{3}{*}{$\begin{array}{l}\text { Valid } \\
\text { informatio } \\
n\end{array}$} & Agree & 4 & 13 & \multirow{3}{*}{$\begin{array}{l}\text { Valid } \\
\text { informatio } \\
n\end{array}$} & Agree & 3 & 10 \\
\hline & Not-Sure & 12 & 39 & & Not-Sure & 11 & 35 \\
\hline & Disagree & 15 & 48 & & Disagree & 17 & 55 \\
\hline \multicolumn{2}{|l|}{ Total } & 31 & 100 & \multicolumn{2}{|l|}{ Total } & 31 & 100 \\
\hline \multirow{3}{*}{$\begin{array}{l}\text { Scientific } \\
\text { argument }\end{array}$} & Agree & 6 & 19 & \multirow{3}{*}{$\begin{array}{l}\text { Scientific } \\
\text { argument }\end{array}$} & Agree & 4 & 13 \\
\hline & Not-Sure & 14 & 45 & & Not-Sure & 3 & 10 \\
\hline & Disagree & 11 & 35 & & Disagree & 24 & 77 \\
\hline \multicolumn{2}{|l|}{ Total } & 31 & 100 & \multicolumn{2}{|l|}{ Total } & 31 & 100 \\
\hline \multirow{3}{*}{$\begin{array}{l}\text { Valid } \\
\text { conclusion }\end{array}$} & Agree & 3 & 10 & \multirow{3}{*}{$\begin{array}{l}\text { Valid } \\
\text { conclusion }\end{array}$} & Agree & 4 & 13 \\
\hline & Not-Sure & 11 & 35 & & Not-Sure & 3 & 10 \\
\hline & Disagree & 17 & 55 & & Disagree & 24 & 77 \\
\hline \multicolumn{2}{|l|}{ Total } & 31 & 100 & \multicolumn{2}{|l|}{ Total } & 31 & 100 \\
\hline
\end{tabular}

مجلة كلية التببة- جامعة عين شمس 66 () العدد الثان والأربعون (الجزء الاول) 2018 
Lolowah Abdulkarim Abrahym Hanan Salah EL-Deen Mohamed Amal Mohamed Hassan Otaiba

Table 6 shows that more students by the end of the course are able to evaluate the validity of presented information than at the beginning of the course.

Table 7. Independent Samples Test

\begin{tabular}{|c|c|c|c|c|c|c|}
\hline & Mean & $\mathrm{F}$ & Sig. & $\mathrm{t}$ & $\mathrm{df}$ \\
\hline \multirow{2}{*}{$\begin{array}{l}\text { Valid } \\
\text { information }\end{array}$} & Pre-test & 1.59 & \multirow{2}{*}{1.053} & \multirow{2}{*}{.309} & -.100 & \multirow{2}{*}{$\begin{array}{l}60 \\
59.755\end{array}$} \\
\hline & Post-test & 1.61 & & & -.101 & \\
\hline \multirow{2}{*}{$\begin{array}{l}\text { Scientific } \\
\text { argument }\end{array}$} & Pre-test & 1.62 & \multirow{2}{*}{1.924} & \multirow{2}{*}{.171} & 1.126 & \multirow{2}{*}{$\begin{array}{l}60 \\
59.465\end{array}$} \\
\hline & Post-test & 1.39 & & & 1.138 & \\
\hline \multirow{2}{*}{$\begin{array}{l}\text { Valid } \\
\text { conclusion }\end{array}$} & Pre-test & 1.38 & \multirow{2}{*}{.249} & \multirow{2}{*}{.620} & -.060 & \multirow{2}{*}{$\begin{array}{l}60 \\
54.485\end{array}$} \\
\hline & Post-test & 1.39 & & & -.620 & \\
\hline
\end{tabular}

Table 7 proves the third hypothesis, the critical thinking training received by students throughout the course enhanced their ability to evaluate the presented information in the ad more accurately than at the beginning of the course.

(4) There is a significant difference between the pre-test scores and the post-test scores on the critical thinking test related to students' ability to identify the deductive assumptions.

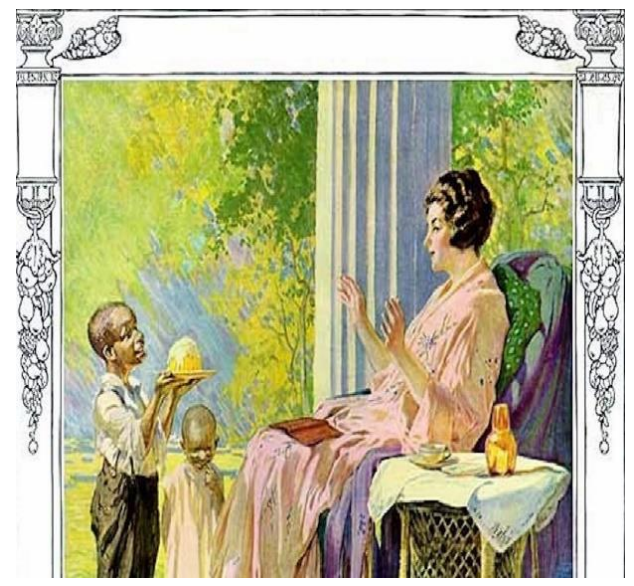

مجلة كلية التربية- جامعة عين شمس 67 () العدد الثانى والأربعون (الجزء الاول) 2018 
Reinforcing moderation: University instructors' role in incorporating social networks to promote critical thinking among female Umm Al-Qura students

Table 8. The distribution of students' scores regarding to their ability to identify the deductive assumptions

\begin{tabular}{|c|c|c|c|c|c|c|c|}
\hline \multicolumn{5}{|l|}{ Pre-test } & \multicolumn{3}{|l|}{ Post-test } \\
\hline & & $\mathrm{N}$ & $\%$ & & & $\mathrm{~N}$ & $\%$ \\
\hline \multirow{3}{*}{$\begin{array}{l}\text { Cultural } \\
\text { message }\end{array}$} & Agree & 13 & 42 & \multirow{3}{*}{$\begin{array}{l}\text { Cultural } \\
\text { message }\end{array}$} & Agree & 12 & 39 \\
\hline & Not-Sure & 10 & 32 & & Not-Sure & 9 & 29 \\
\hline & Disagree & 8 & 26 & & Disagree & 10 & 32 \\
\hline \multicolumn{2}{|l|}{ Total } & 31 & 100 & \multicolumn{2}{|l|}{ Total } & 31 & 100 \\
\hline \multirow{3}{*}{$\begin{array}{l}\text { Moral } \\
\text { message }\end{array}$} & Agree & 18 & 58 & \multirow{3}{*}{$\begin{array}{l}\text { Moral } \\
\text { message }\end{array}$} & Agree & 10 & 32 \\
\hline & Not-Sure & 4 & 13 & & Not-Sure & 5 & 16 \\
\hline & Disagree & 9 & 29 & & Disagree & 16 & 52 \\
\hline \multicolumn{2}{|l|}{ Total } & 31 & 100 & \multicolumn{2}{|l|}{ Total } & 31 & 100 \\
\hline \multirow{3}{*}{$\begin{array}{l}\text { Social } \\
\text { message }\end{array}$} & Agree & 25 & 81 & \multirow{3}{*}{$\begin{array}{l}\text { Social } \\
\text { message }\end{array}$} & Agree & 15 & 48 \\
\hline & Not-Sure & 5 & 16 & & Not-Sure & 6 & 19 \\
\hline & Disagree & 1 & 3 & & Disagree & 10 & 32 \\
\hline \multicolumn{2}{|l|}{ Total } & 31 & 100 & \multicolumn{2}{|l|}{ Total } & 31 & 100 \\
\hline \multirow{3}{*}{$\begin{array}{l}\text { Direct } \\
\text { message }\end{array}$} & Agree & 19 & 61 & \multirow{3}{*}{$\begin{array}{l}\text { Outright } \\
\text { message }\end{array}$} & Agree & 5 & 16 \\
\hline & Not-Sure & 4 & 13 & & Not-Sure & 10 & 32 \\
\hline & Disagree & 8 & 26 & & Disagree & 17 & 55 \\
\hline \multicolumn{2}{|l|}{ Total } & 31 & 100 & \multicolumn{2}{|l|}{ Total } & 31 & 100 \\
\hline
\end{tabular}

Table 8 shows that students since the beginning of the course are able to express a coherent and consistent understanding of the deductive messages this ad presents, but they do so from different perspectives. Most of students at the beginning of the course agree that this Ad carries explicit cultural, moral, and social messages. Whereas, after the end of the course they agree that the ad carries ambiguous cultural, moral, and social messages. This result shows evidence of their ability to practice critical thinking, although this ability emanates from different resources.

Table 9. Independent Samples Test

\begin{tabular}{|c|c|c|c|c|c|c|}
\hline & & Mean & $\mathrm{F}$ & Sig. & $\mathrm{t}$ & $\mathrm{df}$ \\
\hline \multirow{2}{*}{$\begin{array}{l}\text { Cultural } \\
\text { message }\end{array}$} & Pre-test & 2.16 & \multirow{2}{*}{.038} & \multirow{2}{*}{.845} & .455 & \multirow{2}{*}{$\begin{array}{l}60 \\
59.905\end{array}$} \\
\hline & Post-test & 2.06 & & & .455 & \\
\hline \multirow{2}{*}{$\begin{array}{l}\text { Moral } \\
\text { message }\end{array}$} & Pre-test & 2.29 & \multirow{2}{*}{.010} & \multirow{2}{*}{.922} & 2.103 & 60 \\
\hline & Post-test & 1.181 & & & 2.103 & 59.995 \\
\hline Social & Pre-test & 2.77 & 26.304 & $.000 * *$ & 3.324 & 60 \\
\hline
\end{tabular}

مجلة كلية التربية- جامعة عين شمس 68 () العدد الثانى والأربعون (الجزء الاول) 2018 
Lolowah Abdulkarim Abrahym Hanan Salah EL-Deen Mohamed Amal Mohamed Hassan Otaiba

\begin{tabular}{|l|l|l|l|l|l|l|}
\hline \multicolumn{2}{|c|}{} & Mean & F & Sig. & t & df \\
\hline message & Post-test & 2.16 & & & 3.324 & 46.818 \\
\hline \multirow{2}{*}{$\begin{array}{l}\text { Direct } \\
\text { message }\end{array}$} & Pre-test & 2.35 & \multirow{2}{*}{1.855} & .178 & 3.557 & 60 \\
\cline { 2 - 7 } & Post-test & 1.61 & & & 3.557 & 58.815 \\
\hline
\end{tabular}

Table 9 proves the fourth hypothesis, there is a significant difference between the pre-test scores and the post-test scores on the critical thinking test related to students' ability to identify deductive assumptions. However, this significant result proves that different perceptions lead to different critical interpretations of deductive messages.

(5) There is a significant difference between the pre-test scores and the post-test scores on the critical thinking test related to students' ability to identify logical misconceptions.

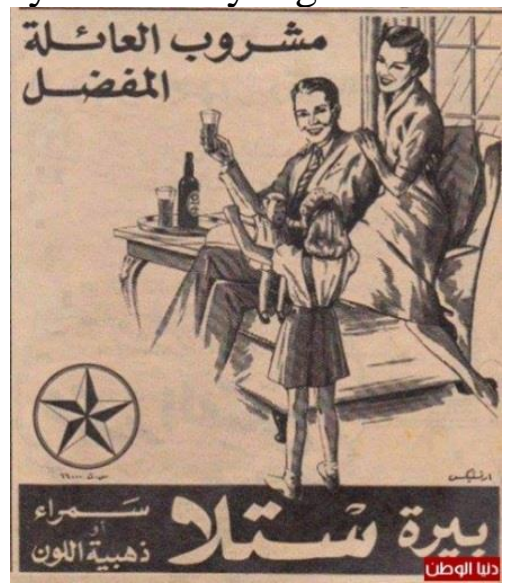

Table 10. The distribution of students' scores in relation to their ability to identify logical misconceptions

\begin{tabular}{|c|c|c|c|c|c|c|c|}
\hline \multicolumn{5}{|l|}{ Pre-test } & \multicolumn{3}{|l|}{ Post-test } \\
\hline & & $\mathrm{N}$ & $\%$ & & & $\mathrm{~N}$ & $\%$ \\
\hline \multirow{3}{*}{$\begin{array}{l}\text { Logical } \\
\text { information }\end{array}$} & Agree & 5 & 16 & \multirow{3}{*}{$\begin{array}{l}\text { Logical } \\
\text { information }\end{array}$} & Agree & 2 & 6 \\
\hline & Not-Sure & 6 & 19 & & Not-Sure & 4 & 13 \\
\hline & Disagree & 20 & 65 & & Disagree & 25 & 81 \\
\hline \multicolumn{2}{|l|}{ Total } & 31 & 100 & \multicolumn{2}{|l|}{ Total } & 31 & 100 \\
\hline \multirow{2}{*}{$\begin{array}{l}\text { Contradicting } \\
\text { information }\end{array}$} & Agree & 21 & 68 & \multirow{2}{*}{$\begin{array}{l}\text { Contradicti } \\
\text { ng }\end{array}$} & Agree & 23 & 74 \\
\hline & Not-Sure & 4 & 13 & & Not-Sure & 5 & 16 \\
\hline
\end{tabular}

$$
\text { مجلة كلية التربية- جامعة عين شمس } 69 \text { () العدد الثان والأربعون (الجزء الاول) } 2018
$$


Reinforcing moderation: University instructors' role in incorporating social networks to promote critical thinking among female Umm Al-Qura students

\begin{tabular}{|c|c|c|c|c|c|c|c|}
\hline \multicolumn{5}{|l|}{ Pre-test } & \multicolumn{3}{|l|}{ Post-test } \\
\hline & Disagree & 6 & 19 & information & Disagree & 3 & 10 \\
\hline \multicolumn{2}{|l|}{ Total } & 31 & 100 & \multicolumn{2}{|l|}{ Total } & 31 & 100 \\
\hline \multirow{3}{*}{$\begin{array}{l}\text { Immoral } \\
\text { information }\end{array}$} & Agree & 23 & 74 & \multirow{3}{*}{$\begin{array}{l}\text { Immoral } \\
\text { information }\end{array}$} & Agree & 29 & 94 \\
\hline & Not-Sure & 1 & 3 & & Not-Sure & 0 & 0 \\
\hline & Disagree & 7 & 23 & & Disag & 2 & 6 \\
\hline \multicolumn{2}{|l|}{ Total } & 31 & 100 & \multicolumn{2}{|l|}{ Total } & 31 & 100 \\
\hline \multirow{3}{*}{$\begin{array}{l}\text { Useful } \\
\text { information }\end{array}$} & Agree & 1 & 3 & \multirow{3}{*}{$\begin{array}{l}\text { Useful } \\
\text { information }\end{array}$} & Agree & 1 & 3 \\
\hline & Not-Sure & 5 & 16 & & Not-Sure & 2 & 6 \\
\hline & Disagree & 25 & 81 & & & 28 & 91 \\
\hline \multicolumn{2}{|l|}{ Total } & 31 & 100 & \multicolumn{2}{|l|}{ Total } & 31 & 100 \\
\hline
\end{tabular}

Table 10 shows that more students at the end of the course can identify the logical misconceptions in the ad than at the beginning of the course. This ad is about a famous beer brand, the Muslim community, beer is prohibited because it contains alcohol.

Table 11. Independent Samples Test

\begin{tabular}{|c|c|c|c|c|c|c|}
\hline & Mean & $\mathrm{F}$ & Sig. & $\mathrm{t}$ & $\mathrm{df}$ \\
\hline \multirow{2}{*}{$\begin{array}{l}\text { Logical } \\
\text { information }\end{array}$} & Pre-test & 1.44 & \multirow{2}{*}{7.351} & \multirow{2}{*}{$.009 * *$} & 1.433 & \multirow{2}{*}{$\begin{array}{l}60 \\
58.776\end{array}$} \\
\hline & Post-test & 1.21 & & & 1.481 & \\
\hline \multirow[b]{2}{*}{$\begin{array}{l}\text { Contradicting } \\
\text { information }\end{array}$} & Pre-test & & \multirow[b]{2}{*}{8.158} & \multirow[b]{2}{*}{$.006 * *$} & & \multirow[b]{2}{*}{$\begin{array}{l}60 \\
59.448\end{array}$} \\
\hline & Post-test & $\begin{array}{l}2.32 \\
2.71\end{array}$ & & & $\begin{array}{l}2.125 \\
- \\
2.186\end{array}$ & \\
\hline \multirow[b]{2}{*}{$\begin{array}{l}\text { Immoral } \\
\text { information }\end{array}$} & Pre-test & & \multirow[b]{2}{*}{22.131} & \multirow[b]{2}{*}{$.000 * *$} & & \multirow[b]{2}{*}{$\begin{array}{l}60 \\
49.473\end{array}$} \\
\hline & Post-test & $\begin{array}{l}2.59 \\
2.93\end{array}$ & & & $\begin{array}{l}2.105 \\
- \\
2.237\end{array}$ & \\
\hline \multirow{2}{*}{$\begin{array}{l}\text { Useful } \\
\text { information }\end{array}$} & Pre-test & 1.15 & \multirow{2}{*}{2.777} & \multirow{2}{*}{.101} & .806 & \multirow{2}{*}{$\begin{array}{l}60 \\
55.334\end{array}$} \\
\hline & Post-test & 1.07 & & & .843 & \\
\hline
\end{tabular}

Table 11 proves the fifth hypothesis, the critical thinking training received by students during their involvement in the course enhanced their ability to identify logical misconceptions.

(6) The critical thinking training that students received positively affects their evaluation of the course scenario and activities.

مجلة كلية التربية- جامعة عين شمس 70 () العدد الثان والأربعون (الجزء الاول) 2018 
Lolowah Abdulkarim Abrahym Hanan Salah EL-Deen Mohamed Amal Mohamed Hassan Otaiba

Figure 1 shows students' degree of satisfaction with the course scenario and activities. The results show that most students were well satisfied with the course activities and specially with the integration of information technology in supporting the course activities, which was rated 5, the maximum evaluation score possible. Additionally, students declared that the way the course was delivered stimulated their interest in the subject (4.9); therefore, their overall evaluation of the course was also a 5.

مجلة كلية التربية- جامعة عين شمس 71 () العدد الثانى والأربعون (الجزء الاول) 2018 
Reinforcing moderation: University instructors' role in incorporating social networks to promote critical thinking among female Umm Al-Qura students

This was a worthwhile class

The course is a positive contribution to my future

Assessment of course wark and tests was fair and.

Feedback was provided with the stated timeframe

The course improved my ability to use social.

The course encouraged me to invest information in.

The course improved my teamwork skill.

The course stimulated my interest in the subject.

Information technology was well invested to...

Projects/assignments related to course learning.

The work load of the course was reasonable

The course was up to date

The course was supported by adequate library

The syllabus was explained at the beginning of the.

The course was delivered as outlined in the syllabus

The instructor was available to assist students

The instructor was accessible outside of class

The instructor challenged students to do their best...

The instructor appeared enthusiastic and interested

The instructor demonstrated in-depth knowledge.

The instructor used a variety of instructional.

The instructor used a variety of instructional Instructor gave guidance on where to find resources The instructor explained how the course related to.. The instructor was committed to deliver the course..

\section{7}

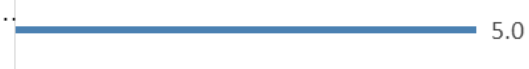

Fig. 1: Students' evaluation of "Introduction to Education" course scenario and activities

$$
\text { مجلة كلية التربية- جامعة عين شمس } 72 \text { () العدد الثانى والأربعون (الجزء الاول) } 2018
$$




\section{Lolowah Abdulkarim Abrahym Hanan Salah EL-Deen Mohamed Amal Mohamed Hassan Otaiba}

\section{Discussion}

Extremism is grounded in the conviction that there is one right answer, one face of truth, and no alternatives. By contrast, critical education is founded on the notion of multiple realities, feeling comfortable with ambiguity, searching for alternative meanings of reality and multiple versions of truth (Davies, 2009, p. 192). For an educational platform, this means that students must be given the chance to engage in a self-regulated, non-linear, and interpretive process of constructing knowledge supported by interacting with social networks (Fosnot \& Perry, 2005, p. 34). The results emerged from this research indicated that interacting with social networks using information technologies during course activities students constructed their knowledge not only in the customary manner of learning but also in an innovative way based on exploring new meanings and ideas. In other words, the dimensions of critical thinking emerged through the features of constructive learning (Topolovčan \& Matijević, 2017, p. 52).

The dimensions of critical thinking as defined in this study, are the distinction between truth and assumption, the distinction between information related to the subject and irrelevant information, the evaluation of information validity, the identification of deductive assumptions; and the identification of logical misconceptions (Beyer, 1985, 1987, 1988). Through participation in the course work, students managed to master these skills as they were involved in an educational environment characterized by interactivity, adaptivity, constructivism, and a meaningful learning process that steered them to socially construct knowledge that makes sense of their world, and challenged them to solve the problems they face (Carwile, 2007; Fosnot \& Perry, 2005; Gold, 2001).

In this context, the university instructor is no longer the main source of knowledge, transferring it to passive students who memorize and recite it without engaging with it, but is a coconstructor of the students' knowledge. From this perspective,

مجلة كلية التربية- جامعة عين شمس 73 () العدد الثاني والأربعون (الجزء الاول) 2018 
Reinforcing moderation: University instructors' role in incorporating social networks to promote critical thinking among female Umm Al-Qura students

learning can independently from teaching, so that students can learn what is not explicitly taught, and instructors can teach without learning (Topolovčan \& Matijević, 2017).

For instructors, a constructive class that incubates critical thinking, teaching and learning strategies must be woven around educational situations that are: inquiry-based, problem-based, and project-based and that, cooperative learning; and learning by doing which are accomplished through the fruitful integration of virtual social networks (Aljaad, 2016; Alkhathlan \& Al-Daraiseh, 2017; Barber \& King, 2016)

Critical thinking in this sense doesn't present the ultimate goal of the educational endeavor; "it is nice you can think but after all what is really important is what you think" (Beyer, 1988, p. 2). Students who participated in this research identify social networks as opportunities to learn critical thinking skills through selfexploration of the outside world with all its opportunities and challenges. In other words, in the current research critical thinking presents a passage to a wider intellectual, virtuous, and peaceful world organized by self-improved citizens and leaders who master collaborative problem-solving skills, are alert to problems as they arise, are capable of processing massive amounts of information, and can find innovative ways to overcome the traditional sociocultural and economic obstacles that have postponed Arabs emergence into the $21^{\text {st }}$ century arena for decades.

\section{Conclusion}

The results that emerged from this research support the assumption that critical thinking is an integral element in transforming traditional forms of Saudi education into a constructive one. In the interim, new social media is important for supporting constructive learning and critical thinking practice, because new social media are an integral element of the learning environment of younger Saudi generations. The results also indicate that the traditional teacher centered learning context can never

$$
\text { مجلة كلية التربية- جامعة عين شمس } 74 \text { () العدد الثان والأربعون (الجزء الاول) } 2018
$$


Lolowah Abdulkarim Abrahym Hanan Salah EL-Deen Mohamed Amal Mohamed Hassan Otaiba

develop critical thinking skills in students, and opening the learning platform for Saudi students to take the lead position is the only guarantee that students will be able to master and practice critical thinking skills in a manner that transcends the learned experiences, bringing these skills to real life situations and to the workplace, particularly since the release of the monarchy's decrees allowing Saudi females the right to drive cars and to travel without the permission of their custodians. These new sociocultural transitions need an educational revolution based on moderation and tolerance that will protect women's emergence into the new labor market from the backlashes of extremism. Therefore, with the growing need for new professional sectors as explained in the 2030 vision education reforms must be at the heart of any Saudi debate and plans.

\section{Acknowledgements}

The authors thank the Center of Social Sciences Research \& Scientific and The Center of Social Studies Research \& Research Deanship at Umm Al-Qura University for their sponsorship of this project. Their support and encouragement facilitated the execution of the two phases "Investing Social Networks in Reinforcing Moderation among Saudi University Students: The Present and the Future".

مجلة كلية التببة- جامعة عين شمس 75 () العدد الثان والأربعون (الجزء الاول) 2018 
Reinforcing moderation: University instructors' role in incorporating social networks to promote critical thinking among female Umm Al-Qura students

\section{References}

Al-Saggaf, Y. (2011). Saudi Females on Facebook: An Ethnographic Study. International Journal of Emerging Technologies and Society, 9(1), 1-19.

Al Mughaseeb, A. A. (2006). Teaching Critical Thinking - Reading in Contemporary Educational Experience. Riyadh: Dar Al Ma'aref Publishing and Distribution.

Aljaad, N. H. M. (2016). The Role of Social Communication Tools in Education from the Saudi Female Students' Perceptions. International Education Studies, 9(8), 194-202.

Alkhathlan, A. A., \& Al-Daraiseh, A. A. (2017). An Analytical Study of the Use of Social Networks for Collaborative Learning in Higher Education. International Journal of Modern Education and Computer Science, 9(2), 1-n/a.

ALQowaifly, L. A. A., EL-Halawany, H. S. E.-d., \& Otaiba, A. M. (2017). The Factual Conducts of Umm Al-Qura Female Students on Social Networks in a Way that Reflects Moderation Journal of Future Education, 24, 297-440.

AlThubaiti, A. D. (2006). Developing critical thinking skills among middle school students through the teaching of the history course according to the model of constructive learning. Journal of the Faculty of Education, Mansoura University, 61(2), 60-82.

AShaya, H., \& Batihah, M. I. (2013). A proposal to employ the social networks of university students in the Kingdom of Saudi Arabia based on the reality of their use. Education, 2(2).

Barber, W., \& King, S. (2016). Teacher-Student Perspectives of Invisible Pedagogy: New Directions in Online Problem-Based Learning Environments. Electronic Journal of e-Learning, 14(4), 235-243.

Beyer, B. K. (1985). Critical thinking what is it? Social Education, 49(4).

Beyer, B. K. (1987). Practice is not enough. In M. Heiman \& J. Slomianko (Eds.), Thinking skills instruction: Concepts and

مجلة كلية التربية- جامعة عين شمس 76 () العدد الثانظ والأربعون (الجزء الاول) 2018 


\section{Lolowah Abdulkarim Abrahym Hanan Salah EL-Deen Mohamed Amal Mohamed Hassan Otaiba}

techniques (pp. 77- 87): National Education Association of the United States.

Beyer, B. K. (1988). Hints for imporving the teaching of thinking in our schools: A baker's dozen. Institute of Critical Thinking Resource Publication, 1(4), 1-10.

Carwile, J. (2007). A constructivist approach to online teaching and learning. Inquiry, 12(1), 68-73.

Churcher, K. M., Downs, E., \& Tewksbury, D. (2014). "Friending" Vygotsky: A Social Constructivist Pedagogy of Knowledge Building Through Classroom Social Media Use. The Journal of Effective Teaching, 14(1), 33-50.

Davies, L. (2009). Educating Against Extremism: Towards a Critical Politicisation of Young People. International Review of Education, 55(2-3), 183-203. doi:http://dx.doi.org/10.1007/s11159-008-9126-8

Fosnot, C. T., \& Perry, R. S. (Eds.). (2005). Constructivism: A psychological theory of learning. New York, NY: Teacher College Press.

Gavilan, D., Martinez-Navarro, G., \& Fernández-Lores, S. (2017). University Students and Informational Social Networks: Total Sceptics, Dual Moderates or Pro-Digitals. [Universitarios y redes sociales informativas: Escépticos totales, moderados duales o prodigitales]. Comunicar, 25(53), 61-70. doi:http://dx.doi.org/10.3916/C53-2017-06

Gold, S. (2001). A constructivist approach to online training for online teachers. Journal of Asynchronous Learning Networks, 5(1), 3557.

Hariri, K. H. (2010). Promoting the values of moderation and moderation among young people. Retrieved from AlMithaq.net website: http://www.almethaq.net/news/news-17402.htm

Kingdom of Saudi Arabia. (2016a). The National Transformation Program. Retrieved from http://vision2030.gov.sa/sites/default/files/NTP En.pdf

مجلة كلية التربية- جامعة عين شمس 77 () العدد الثان والأربعون (الجزء الاول) 2018 
Reinforcing moderation: University instructors' role in incorporating social networks to promote critical thinking among female Umm Al-Qura students

Kingdom of Saudi Arabia. (2016b). Vision 2030. Retrieved from http://vision2030.gov.sa/en/foreword

Koohang, A., Riley, L., Smith, T., \& Schreurs, J. (2009). E-learning and constructivism: From theory to application. Interdisciplinary Journal of E-Learning and Learning Objects, 5, 91-109.

Ladyshewsky, R. K. (2006). Peer coaching: A constructivist methodology for enhancing critical thinking in postgraduate business education. Higher Education Research \& Development, 25(1), 67-84. doi:10.1080/13600800500453196

Larzelere, H. (2015). Social media must be monitored for terrorism promotion. University Wire; Carlsbad.

Laurence, J. (2007). Review: The Prophet of Moderation: Tariq Ramadan's Quest to Reclaim Islam. Foreign Affairs, 86(3).

Löfström, E., \& Nevgi, A. (2006). From strategic planning to meaningful learning: Diverse perspectives on the development of web-based teaching and learning in higher education. British Journal of Educational Technology, 38, 312-324.

Murphy, E., \& Rodriguez-Manzanares, M. A. (2009). Sage without a stage: Expanding the object of teaching in a web-based, highschool classroom. International Review Of Research In Open And Distance Learning, 10(3), 1-19.

Overbaya, A., Patterson, A. S., Vasua, E. S., \& Grablec, 1. L. (2010). Constructivism and technology use: Findings from the IMPACTing leadership project. Educational Media International, 47, 103-120.

Paul, R., \& Elder, L. (2003). The miniature guide to critical thinking concepts \& tools. Dillon Beach, CA: Foundation for Critical Thinking.

Radwan, I. (2000). A pilot study - a program in the development of critical thinking among students of the Faculty of Education Ain Shams University. Journal of Studies in Curriculum and Teaching

مجلة كلية التببة- جامعة عين شمس 78 () العدد الثانف والأربعون (الجزء الاول) 2018 
Lolowah Abdulkarim Abrahym Hanan Salah EL-Deen Mohamed Amal Mohamed Hassan Otaiba

Methods, Egyptian Society for Curriculum and Teaching Methods Faculty of Education-Ain Shams University, 66, 4-34.

Saunders, M., Lewis, P., \& Thornhill, A. (2014). Research methods for business students. Harlow, Essex, England: Pearson Education Limited.

Thormann, J., \& Fidalgo, P. (2014). Guidelines for Online Course Moderation and Community Building from a Student's Perspective. Journal of Online Learning \& Teaching, 10(3), 374388.

Thormann, J., Gable, S., Fidalgo, P. S., \& Blakeslee, G. (2013). Interaction, Critical Thinking, and Social Network Analysis (SNA) in Online Courses. International Review of Research in Open \& Distance Learning, 14(3), 294-317.

Topolovčan, T., \& Matijević, M. (2017). Critical Thinking as a Dimension of Constructivist Learning: Some of the Characteristics of Students of Lower Secondary Education in Croatia. [Kritično mišljenje kot dimenzija konstruktivističnega učenja: nekatere značilnosti učencev predmetne stopnje osnovne šole na Hrvaškem]. CEPS Journal : Center for Educational Policy Studies Journal, 7(3), 47-66.

Winograd, D. (2000). The effects of trained moderation in online asynchronous distance learning. Paper presented at the Proceedings of the National Convention of Associations for Educational Communication and Technology ' 00 ', Denver.

Yoon, I. (2016). Why is it not Just a Joke? Analysis of Internet Memes Associated with Racism and Hidden Ideology of Colorblindness. Journal of Cultural Research in Art Education, 33, 92-123.

مجلة كلية التربية- جامعة عين شمس 79 () العدد الثاني والأربعون (الجزء الاول) 2018 
Reinforcing moderation: University instructors' role in incorporating social networks to promote critical thinking among female Umm Al-Qura students

مجلة كلية التربية- جامعة عين شمس 80 () العدد الثانى والأربعون (الجزء الاول) 2018 